\title{
PENINGKATANAKTIVITAS DAN HASIL BELAJAR SISWA DALAM PEMBELAJARAN IPS MELALUI METODE DEMONSTRASI PADA KELAS VII SEMESTER II DI SMP NEGERI I GIANYAR
}

\author{
Anak Agung Gede Agung Darmawan \\ SMP Negeri I Gianyar \\ agungbima9999@yahoo.com
}

\begin{abstract}
Abstrak
Penelitian Tindakan Kelas (PTK) ini bertujuan untuk meningkatkan aktivitas dan hasil belajar siswa Kelas VII di SMP Negeri I Gianyar melalui pengimplementasian metode demonstrasi dalam pembelajaran. PTK dilakukan dalam dua siklus, tiap siklus terdiri dari tiga kali pertemuan. Data dikumpulkan melalui observasi dan test yang selanjutnya diolah dan kemudian dianalisis secara deskriptif kualitatif. Hasil penelitian menunjukkan bahwa dengan metode demonstrasi, aktivitas siswa Kelas VII di SMP Negeri I Gianyar yang terlibat dalam pembelajaran mengalami peningkatan dari $25 \%$ pada Siklus I menjadi $85 \%$ pada siklus II. Hasil belajar siswaterdapat peningkatan, yaitu dari yang semula nilai rata-ratanya hanya 60,14 menjadi 65,14 pada siklus I dan menjadi 71,86 pada siklus II. Sedangkan ketuntasan belajar siswa meingkat dari yang semula hanya dari $22,86 \%$ menjadi $28,57 \%$ pada siklus I dan menjadi $82,86 \%$ pada siklus II. Hal tersebut menunjukkan bahwa pengimplementasian metode demonstrasi dalam pembelajaran IPS pada Kelas VII di SMP Negeri I Gianyar dapat menjadi solusi dalam meningkatkan aktivitas dan hasil belajar siswa bersangkutan.
\end{abstract}

Kata Kunci:peningkatan, metode demonstrasi, aktivitas belajar, hasil belajar.

\section{PENDAHULUAN}

Pendidikan merupakan kata kunci yang harus dijadikan prioritas dalam pembangunan SDM yang unggul. Tilaar (2001) mendefinisikan pendidikan sebagai suatu proses hominisasi (proses menjadi homo/manusia) dan humanisasi (proses menjadi human/manusiawi) yang berlangsung dalam lingkungan keluarga serta masyarakat yang berbudaya. Definisi itu menunjukkan bahwa secara mendasar pendidikan mengandung pengertian sebagai proses untuk menjadikan peserta didik sebagai manusia yang manusiawi melalui pembelajaran yang dilakukan.

Terdapat dua faktor yang berpengaruh terhadap pembelajaran, yaitu faktor eksternal (dari luar) danfaktor internal (dari dalam).
Faktor dari luar terdiri dari faktor lingkungan (enviromenta), dan faktor instrumental. Faktor instrumental meliputi kurikulum, program, sarana dan prasarana, biaya, faktor administrasi serta guru. Sedangkan faktor dari dalam meliputi keadaan psikologi umum dan kondisi panca indra.Keadaan psikologis meliputi minat, kecerdasan, bakat, motivasi dan kemampuan kognitif (Nasution, 1994).

Belum optimalnya pembelajaran yang terimplementasikan akan berdampak pada rendahnya hasil belajar yang dicapai siswa. Belum optimalnya pembelajaran dapat disebabkan oleh guru yang belum menerapkan metode pembelajaran yang sesuai,sehingga pembelajaran menjadi tidak menarik 
dan siswa tidak aktif. Suatu kondisi belajar yang optimal dapat dicapai jika guru mampu mengatur siswa dan sarana pembelajaran, serta mampu mengendalikannya dalam suasana yang menyenangkan untuk mencapai tujuan. Pengaturan yang dimaksud bersifat langsung berkenaan dengan penyampaian pesan dalam wujud materi pembelajaran, yaitu dengan menyediakan kondisi menyenangkan melalui pengelolaan kelas yang dilakukan guru.

Hasil belajar siswa kelas VII di SMP Negeri I Gianyar untuk mata pelajaran IPS dilihat dari hasil ulangan hariannya yang telah dilaksanakan secara klasikal, masih cenderung rendah. Rata-rata kelas yang dicapai siswa masih di bawah 60 , sementara KKM yang telah ditetapkan untuk mata pelajaran IPS adalah 70. Selain itu, pembelajaran IPS yang telah dilaksanakan selama ini juga menunjukkan rendahnya aktivitas siswa selama proses pembelajaran berlangsung.

Berdasarkan hasil refleksi yang dilakukan, ternyata sebagian besar masalah yang terjadi diakibatkan oleh proses belajar mengajar. Pembelajaran yang dilakukan guru selama ini lebih didominasi oleh metode ceramah. Diskusi kelas dan tanya jawab hampir tidak pernah dilakukan. Dalam hal ini, gurulah yang bersifat aktif untuk memberikan ceramah, sementara siswa hanya sebagai pendengar yang setia. Di samping itu, guru juga dalam pembelajaran belum menggunakan media. Guru hanya mengandalkan buku wajib untuk mata pelajaran IPS. Dampak dari pembelajaran tersebut menyebabkan siswa menjadi pasif yang akhirnya berdampak pada hasil belajar siswa.

Hasil wawancara dengan siswa menunjukkan bahwa orang tua siswa lebih cenderung mengarahkan anak-anaknya untuk mempelajari mata pelajaran IPA atau Matematika atau Bahasa Inggris. Mata pelajaran IPS menurut persepsi orang tua siswa seperti tidak akan membentuk kecerdasan pada anak. Pandangan tersebut wajar, karana kecerdasan yang dipahami saat ini oleh sebagian orang masih terbatas pada kecerdasan intelektual yang bertumpu pada IQ. Gardner (1983) mengemukakan, selain IQ teridentifikasi sembilan macam kecerdasan atau talenta, yang kemudian dikenal sebagai kecerdasan ganda (Multiple Intelligence) atau biasa disingkat dengan Ml. Kesembilan jenis kecerdasan tersebut adalah: (1) musical/rhythmic intelligence, (2) bodily/kinesthetic intelligence, (3) logical/mathematical intelligence, (4) visual/spatial intelligence, verbal/linguistic intelligence, interpersonal intelligence, dan (7) intrapersonal intelligence, naturalistic intelligence dan (9) existention intelligence. IPS lebih berperan dalam memperkuat kecerdasan spasial, kecerdasan antar dan inter personal pada seorang anak sebagai penyeimbang kecerdasan intelektual.

Hasil observasi awal yang dilakukan sebagaiman telah diungkapkan teridentifikasi sejumlah penyebab yang mengakibatkan kurang aktif dan rendahnya hasil belajar siswa di Kelas VII pada semester II di SMP Negeri I Gianyar dalam mata pelajaran IPS, yaitu: (1) pembelajaran masih dodominasi oleh metode ceramah; (2) pembelajaran dengan diskusi dan tanya jawab belum dilakukan dalam usaha menunjang berkembangnya aktivitas siswa; (3) belum digunakannya media pembelajaran; (4) kurangnya perhatian siswa terhadap pelajaran IPS.

Berdasarkan permasalah yang ada dan identifikasi terhadap penyebab permasalahan tersebut, pemecahan masalah yang ditawarkan adalah dengan menerapkan 
"metode demonstrasi".Pemilihan metode demonstrasi untuk memecahkan masalah tersebut berdasarkan pertimbangan akademik setelah berdiskusi dengan teman-teman sejawat dan dosen Undiksha selaku pengarah dalam penelitian ini. Penggunaan metode demonstrasi dinilai akan dapat menghidupkan suasana kelas dibandingkan bila siswa membaca atau hanya mendengarkan. Melalui peragaan yang dilakukan juga akan memberikan gambaran konkrit serta memperjelas pencermatan siswa pada materi yang dipelajari.

Selain itu, melalui metode demonstrasi siswa akan dapat terlibat secara langsung dalam suatu kegiatan yang bersifat mengembangkan kecakapan dan setiap siswa berpeluang memperoleh penghargaan sesuai hasil yang diperoleh. Dengan metode demonstrasi juga akan memudahkan pemusatan perhatian siswa pada hal yang dipandang penting, dan memungkinkan para siswa mengajukan pertanyaan atas apa yang belum dipahami selama demonstrasi berjalan, karena guru dapat memberikan jawaban pada saat itu juga.

Bertitik tolak pada permasalahan yang telah dikemukakan dan pemecahan masalah yang menjadi solusinya, dapat dirumuskan masalah, yaitu: (1) apakah metode demonstrasi yang diimplementasikan dalam pembelajaran IPS dapat meningkatkan aktivitas belajar siswa Kelas VII di SMP Negeri I Gianyar?; (2) apakah metode demonstrasi yang diimplementasikan dalam pembelajaran IPS dapat meningkatkan hasil belajar siswa Kelas VII di SMP Negeri I Gianyar?

\section{METODE}

Penelitian ini dirancang sebagai Penelitian Tindakan Kelas (PTK), yang dilaksanakan untuk memperbaiki pembelajaran di Kelas
VII SMP Negeri I Gianyar, Kabupaten Gianyar. Objek yang diteliti dalam penelitian ini adalah "peningkatan aktivitas dan hasil belajar siswa dalam mata pelajaran IPS melalui metode demonstrasi". Berkenaan dengan itu, yang dijadikan subjek penelitian dalam PTK ini adalah "siswa Kelas VIISMP Negeri I Gianyar" serta guru sebagai perencana, pelaksana, pelapor PTK.

PTK dirancang dalam dua siklus, dan setiap siklus terdiri dari perencanaan, pelaksanaan tindakan, observasi/evaluasi dan refleksi yang dilaksanakan dalam tiga kali pertemuan mengacu pada model yang dikembangkan oleh Hopkins (1993). Data dikumpulkan menggunakan lembar observasi (data: situasi pembelajaran dan aktivitas pembelajaran siswa) dan test (hasil belajar siswa).

Setelah data terkumpul, langkah selanjutnya adalah melakukan pengolahan data, dengan menggunakan formula seperti berikut.

1) Menghitung Tingkat Aktivitas Siswa

Aktivitas dinyatakan tinggi, apabila $75 \%$ dari jumlah siswa aktif dalam kegiatan diskusi setelah peragaan dilakukan oleh guru.

2) Menghitung Nilai Rata-Rata

$$
\bar{x}=\frac{\sum x}{n}
$$

Keterangan: $\bar{x}=$ rata-rata; $\sum \mathrm{x}=$ jumlah nilai; $n \quad=$ jumlah siswa

3) Menghitung Ketuntasan Belajar Untuk menghitung ketuntasan belajar pada mata pelajaran IPS berpedoman pada Kurikulum 2013 SMP Negeri I Gianyar. Rumus yang digunakan adalah :

$$
\mathrm{KB}=\frac{n \geq 70}{N} \times 100 \%
$$


Keterangan: $\mathrm{KB}=$ ketuntasan belajar; $\mathrm{n} \geq 70=$ banyak siswa memperolehnilai $\geq 70 ; \mathrm{N}=$ jumlah siswa

4) Menentukan Kategori Hasil Belajar Siswa

$$
\begin{aligned}
& \text { Daya serap klasikal = } \\
& \frac{\text { Rata-ratakelas }}{100} \times 100 \%
\end{aligned}
$$

5) Menentukan Tingkat Keberhasilan Siswa

Untuk menentukan kategori tingkat keberhasilan belajar siswa dilakukan dengan cara membandingkan angka rata-rata persentase dengan lima kreteria di bawah ini

\section{Tabel 01. KriteriaTingkat} Keberhasilan Siswa

\begin{tabular}{|c|l|}
\hline Persentase & $\begin{array}{c}\text { Tingkat } \\
\text { Keberhasilan }\end{array}$ \\
\hline $\mathbf{( 1 )}$ & \multicolumn{1}{c|}{$(\mathbf{2})$} \\
\hline $90-100$ & Sangat baik \\
\hline $75-89$ & Baik \\
\hline $60-70$ & Cukup \\
\hline $45-59$ & Kurang \\
\hline $0-44$ & Sangat kurang \\
\hline
\end{tabular}

Analisisdata dilakukan secara deskriftif kualitatif dengan pemaknaan secara kontekstual. Penggunaan teknik analisis data ini dilandasi atas kenyataan bahwa PTK merupakan penelitian yang bertujuan untuk memperbaiki kualitas proses dan hasil pembelajaran (mata pelajaran IPS) dengan mengembangkan suatu pola pembelajaran yang dipandang tepat untuk pencapaian tujuan yang telah ditetapkan.

\section{HASIL DAN PEMBAHASAN}

Berdasarkan penelitian yang telah dilakukan selama satu semester, yaitu pada semester II
Tahun akademik 2015/2016, dapat dikemukakan hasil penelitian dan pembahasan sebagai berikut.

\section{Hasil Penelitian}

a. Kondisi Awal

Berpijak pada permasalahan pembelajaran sebagaimana yang telah diuraikandalam latar belakang maka dilakukan test awal pada hari Kamis, 29 Januari 2015 dengan menggunakan rubrik penilaian yang telah disusun dan disepakati.Hasil test menunjukkan bahwa kemampuan siswa dalam dalam memahami konsep-konsep dalam materi Interaksi Sosial dan Sosialisasi masih tergolong rendah.Dari 35 orang siswa Kelas VII yang hadir pada pelaksanaan tes awal hanya 8 orang $(22,86 \%)$ yang tuntas, dan 27 orang $(77,14 \%)$ belum tuntas. Nilai terendah 50 , dan yang tertinggi adalah 70 dengan daya serap siswa $60,14 \%$.

Untuk mengetahui ketuntasan belajar siswa secara klasikal, data dibandingkan dengan nilai KKM (Kriteria Ketuntasan Minimal) yang diberlakukan di Kelas VII SMP Negeri I Gianyar sebagai patokan, yaitu angka 70 . Kekurangan yang menonjol dilakukan oleh sebagian besar siswa, adalah sulit mengingat, menghafalkan, dan memperagakan.

Dalam mencari suatu pemecahan masalah yang dilakukan di kelas terkesan masih ngawur dan rancu dan kurang menguasai cara dalam pemecahan suatu masalah. Hal ini menyebabkan kurang terjalin kontek pembelajaran yang sesuai dengan yang diharapkan, substansi presentasi dangkal, kurang detil, dan kurang menambah wawasan, dan susunannya kurang sistematis. Secara ringkas data tes awal disampaikan pada tabel berikut ini. 
Tabel 02. Data Tes Awal Hasil Belajar IPS Siswa

\begin{tabular}{|c|c|c|c|c|c|}
\hline No & Nilai & Frekuensi & $\begin{array}{c}\text { Jumlah } \\
\text { Nilai }\end{array}$ & Nomor absen Siswa & Ket \\
\hline (1) & (2) & (3) & (4) & (5) & (6) \\
\hline 1 & 50 & $8(22,86 \%)$ & 400 & 1. 5.7.11.19.25.30.35 & BT \\
\hline 2 & 55 & $2(05,71 \%)$ & 110 & 15.22 & BT \\
\hline 3 & 60 & $14(40,00 \%)$ & 840 & $\begin{array}{l}\text { 2. 6.9.10.13.14.17.18.23. } \\
26.27 .29 .31 .33\end{array}$ & BT \\
\hline 4 & 65 & $3(08,57 \%)$ & 195 & 3.21 .28 & BT \\
\hline 5 & 70 & $8(22,86 \%)$ & 560 & 4.8.12.16.20.24.32.34 & $T$ \\
\hline \multicolumn{2}{|l|}{$\mathrm{N}$} & $35(100 \%)$ & & & \\
\hline \multicolumn{2}{|l|}{$\sum X$} & & 2105 & & \\
\hline \multicolumn{2}{|c|}{ Rata-rata } & & 60,14 & & \\
\hline \multicolumn{2}{|c|}{ Daya serap } & & $60,14 \%$ & & \\
\hline \multicolumn{2}{|c|}{ Ketuntasan } & & $22,86 \%$ & & \\
\hline \multicolumn{6}{|c|}{ Sumber: Lampiran 05.} \\
\hline & & $\begin{array}{l}=68 \\
=\text { Belum } \\
=\text { Tuntas }\end{array}$ & & & \\
\hline
\end{tabular}

\section{b. Perencanaan Pembelajaran}

Hasil refleksi awal melakukan pengkajian tentang solusi yang akan dilakukan dalam pembelajaran, sehingga aktivitas dan hasil belajar siswa dapat ditingkatkan. Hasil pengkajian tersebut memutuskan untuk menggunakan "metode demonstrasi" sebagai metode utama dalam melakukan pembelajaran. Hal ini dilandasi bahwa dalam pembelajaran IPS, yang paling diutamakan adalah bagaimana seorang anak dapat melaksanakan interaksi sosial dalam masyarakatnya. Melalui peragaan yang dilakukan diharapkan seorang anak tidak saja menjadi paham, tetapi juga dapat menjadikannya role model(panutan) dan pada akhirnya dapat membiasakan diri untuk melakukannya.

Skenario pembelajaran untuk mengimplementasikan metode demonstrasi dalam pembelajaran dirancang yang selanjutnya dituangkan dalam Perencanaan Pelaksanaan Pembelajaran (RPP).

\section{c. Pelaksanaan Siklus I}

Tindakan siklus I dilaksanakan dalam tiga kali pertemuan dengan pokok bahasan Interaksi Sosial dan Sosialisasi. berlangsung pada hari Kamis, 12 Pebruari 2015jam pelajaranl-2, pertemuan II pada hari Kamis, 12 Juli 2015 jam pelajaran 1-2, dan pertemuan III pada hari Kamis, 26 Juli 2015 jam pelajaran 1-2. Semua siswa Kelas VIlhadir baik pada pertemuan I, II maupun III. Pada siklus ini diimplementasikan rencana tindakan yang terdapat pada skenario pembelajaran (RPP). Pelaksanaan tindakan siklus I secara rinci diuraikan pada bagian berikut ini.

a) Deskripsi Kegiatan Pembelajaran Siklus I

1) Pertemuan I

Pada pertemuan pertama pada hari Kamis, 12 Pebruari 2015. Setelah guru melakukan apersepsi dilanjutkan dengan kegiatan untuk membahas mengenai beberapa topik bahasan dalam pembelajaran sesuai dengan RPP, yaitu Interaksi Sosial dan Sosialisasi sesuai dengan Standar Kompetensi (SK) 3.1. yang mencakup memahami jenis-jenis kelembagaan sosial, budaya, ekonomi dan politik dalam masyarakat.

Pada kegiatan inti guru menyampaikan materi Interaksi 
Sosial dan Sosialisasi dan kapan dan bagaimana hal tersebut mesti dilakukan.Setelah guru menyajikan materi tersebut kemudian guru memperlihatkan gambar-gambar tentang sikap pada saat berinteraksi sosial dan mempraktekan berbagai peristiwa, baik berkenaan dengan interaksi sosial maupun dalam melakukan sosialisasi di masyarakat, sambil memberi beberapa penjelasan. Usaha mengaktifkan siswa, guru juga melakukan beberapa kuis kecil dalam hal membangkitkan semangat siswa dalam mengikuti pelajaran. Kemudian siswa satu persatu diminta kedepan kelas pemperagakan aktivitas interaksi sosial maupun sosialisasi secara bergantian.

Mengakhiri peragaan, guru melakukan beberapa penyimpulan awal dan menyarankan agar siswa juga melakukan penarikan suatu kesimpulan. Pada akhir pertemuan guru memberikan suatu tugas, yaitu melaporkan peristiwa yang berkaitan dengan interaksi sosial dan sosialisasi yang terdapat di masyarakat sekitar siswa tinggal. selanjutnya guru melakukan suatu penyimpulan dan mengimformasikan tentang pembelajaran yang akan datang, serta ditutup dengan mengucapkan salam.

\section{2) Pertemuan II}

Pertemuan II pada siklus I dilaksanakan pada hari Kamis, 19 Pebruari 2015 jam pelajaran 1-2. Setelah mengucapkan salam, guru melakukan absensipembelajaran dilanjutkan dengan topik netral sambil menyampaikan Standar Kompetensi (SK) yaitu 3.2. Memahami pengertian dinamika interaksi manusia dengan lingkungan alam, sosial, budaya, dan ekonomi.

Setelah itu gurumulai melakukan apersepsi,dan penyampian indikator pembalajaran sebagai kompetensi yang dimiliki siswa. Kemudian guru mendemontrasikan peristiwa interaksi antara manusia dan lingkungannya melalui LCD. Selanjutnya guru mulai meminta siswa untuk memperhatikan tayangan di LCD dengan diselingi pertanyaan-pertanyaan kecil. Setelah mengakhiri peragaan, siswa diminta satu persatu untuk mendemonstrasikan ke depan kelas apa yang sudah dicermati melalui LCD.Mengakhiri pembelajaran, guru bersama siswa melakukan diskusi kecil tentang materi yang sudah diberikan yang dilanjutkan dengan gerakan pendinginan, berbaris, pemberian tugas-tugas, evaluasi proses pembelajaran kemudian ditutup dengan salam.

\section{3) Pertemuan III}

Pertemuan ketiga dilaksanakan pada hari Kamis minggu ketiga tanggal 26 Pebruari 2015. Sebagai langkah pendahuluan, guru mengucapkan salam dan dilanjutkan dengan melakukan presensi, apersepsi,dan menanyakan kesiapan siswa untuk melaksanakan tes. Kegiatan inti, siswa diberikan soalsoal terkait dengan materi pada pertemuan 1 dan 2. Siswa pun mengejakan tes dengan serius. Mengakhiri pembelajaran, guru bersama siswa melakukan evaluasi dan penyimpulan dari beberapa konsep dasar dalam interaksi antara manusia dengan lingkungannya dan dilanjutkan dengan melakukan doa dan menutup pertemuan hari itu dengan menyampaikan salam penutup.

b) Hasil Tindakan Siklus I

Hasil implementasi tindakan siklus I tersebut dapat dijabarkan sebagai berikut. ini.

1) Hasil Tes Akhir merupakan kemampuan siswa memperagakan interaksi sosial dan sosialisasi dan menjelaskannya secara lisan.

2) Hasil tes akhir siklus I menunjukkan bahwa kemampuan siswa memperagakaninteraksi 
sosial dan sosialisasi dan menjelaskannya secara lisan sudah mengalami perubahan menjadi lebih baik dibandingkan dengan sebelum dilaksanakan siklus I. Secara umumsudah terdapat peningkatan kemampuan siswa dalam memperagakan interaksi sosial dan sosialisasi sesuai dengan konten yang telah dijelaskan maupun yang dimonstrasikan guru dibandingkan sebelum dilakukan siklus I. Namun,masih terdapat beberapa siswa yang belum mampu memahami secara konseptual. Siswa tidak lagi kesulitan dan berpikir lama-lama untuk mengawali dalam mempresentasikan yang berkaitan dengan interaksi sosial dan sosialisasi. Penjelasan lisannya sudah cukup lancar, sudah cukup sistematis, konten penjelasan lisan siswa semakin lengkap dan rinci. Hanya pada beberapa siswa masih memperlihatkan presentasinya seperti menghafal, kurang menguasai topik, sehingga secara konseptual dipandang belum menguasai.
3) Kelemahan yang terjadi pada hampir sebagian besar siswa adalah keragu-raguan peran sertanya dalam diskusi/ tanya jawab, kekurangan dalam menguasai bahan yang diperagakan, kurang ekspresi dan kurang mampunya siswa dalam menemukan cara yang mudah untuk mendukung penyampaian sebuah pertanyaan.

4) Hasil tes akhir menunjukkan bahwa siswa yang belum tuntas dalam Kompetensi Dasar tersebut berkurang yaitu dari 27 orang pada tes awal menjadi 25 orang. Hal tersebut memperlihatkan sudah terdapat peningkatan. Namun, walaupun sudah ada peningkatan, nilai yang diperoleh siswa masih tergolong rendah.

5) Secara rinci dapat diuraikan, dari 35 orang siswa yang dites, baru 10 orang yang tuntas. Ketuntasan belajar klasikal terdapat dalam hasil tersebut di atas secara ringkas disajikan pada tabel berikut ini.

Tabel 03. Data Tes Hasil Belajar IPS Siswa Pada Siklus I

\begin{tabular}{|l|r|r|r|r|r|}
\hline No & $\begin{array}{r}\text { Nilai } \\
\text { Test }\end{array}$ & $\begin{array}{r}\text { Freku- } \\
\text { ensi }\end{array}$ & $\begin{array}{c}\text { Jumlah } \\
\text { Nilai }\end{array}$ & Nomor Absen Siswa & Ket \\
\hline 1 & 60 & 16 & 960 & 1.2 .5 .7 .11 .15 .18 .19 .22 .23 .25 .26 .27 .29 .30 .35 & BT \\
\hline 2 & 65 & 9 & 585 & 3.6 .9 .10 .13 .14 .17 .31 .33$. & BT \\
\hline 3 & 70 & 3 & 210 & 4.8 .12$. & $\mathrm{T}$ \\
\hline 4 & 75 & 7 & 525 & 16.20 .21 .24 .28 .32 .34 & $\mathrm{~T}$ \\
\hline $\mathrm{N}$ & 35 & & & \\
\hline$\sum \mathrm{X}$ & & 2280 & & \\
\hline \multicolumn{2}{l|l}{ Rata-rata Kelas } & 65,14 & & \\
\hline \multicolumn{2}{l}{ Daya Serap } & $65,14 \%$ & & \\
\hline \multicolumn{2}{l}{ Ketuntasan } \\
\hline
\end{tabular}

Sumber: Lampiran 07.

Keterangan : BT = Belum Tuntas $\quad \mathrm{T}=$ Tuntas

Berdasarkan hasil uraian di atas, dapat dikatakan bahwa implementasi tindakan siklus I ini menimbulkan dampak positif. Adapun dampak positif yang timbul adalah: (1) siswa senang dan tumbuh minatnya untuk belajar lebih aktif dan kreatif guna menumbuhkan cara belajar efektif dan proses pembelajaran tidak membosankan; 
(2) pertanyaan pemandu yang diberikan guru untuk menggiring siswa dalam menemukan isi pokok bahan ajar dan pokok-pokok peristiwa pada peragaan betul-betul berfungsi dengan baik, sehingga memancing tumbuhnya aktivitas fisik dan intelektual siswa selama proses pembelajaran.

Namun, walaupun dampak positif yang timbul cukup banyak ternyata dampak negatifnya juga masih ada, yaitu: (1) diskusi kelompok untuk menentukan pokokpokok peristiwa di didalam buku tampaknya tidak efektif diberlakukan di Kelas VIlini; (2) kemampuan siswa secara umum masih rendah, walaupun sudah ada peningkatan. Penyebabnya adalah siswa kurang mampu berekspresi, siswa belum mampu menguasai konten materi secara konseptual.

\section{c) Refleksi}

Berpedoman pada hasil analisis data seperti yang diuraikan di atas, selanjutnya diadakan refleksi. Pada tahap refleksi dilibatkan teman guru yang bertindak sebagai pengamat atau observer. Karena hasil masih tergolong rendah dengan ketuntasan belajar klasikal baru $28,57 \%$ (belum mencapai target keberhasilanyaitu ketuntasan belajar klasikal minimal $70 \%$ ).

Melalui siklus I, walaupun sudah memperlihatkan adanya peningkatan,namun dari refleksi diputuskan untuk melakukan tindakan siklus II. Adapun yang disempurnakan adalah: (1) siswa diberikan kesempatan untuk menanyakan bagian-bagian yang belum jelas dengan memanfaatkan pedoman buku yang dimodifikasi menjadi kegiatan tanya jawab multiarah untuk membahas isi dari buku bacaan; (2) tanya jawab dengan siswa untuk mencari tahu hal-hal apa yang belum bisa dipahami oleh siswa. Memberikan kesepakatan kepada siswa untuk berlatih mendemontrasikan mendemonstrasikan dengan kelompoknya masing-masing; (3) mengubah gambar sebagai bahan dalam penyampaian materi. Pada siklus I gambar yang digunakan berbentuk visual, sedangkan pada siklus llgambar yang ditampilkan adalah gambar hidup dalam bentuk audio visual; (4) gambar (alat peraga) pada siklus II ini dinilai oleh peneliti memiliki tingkat kesukaran yang seimbang dengan gambar pada siklus I bahkan dinilai lebih menguntungkan untuk semua siswa karena pengubahan topik gambar sengaja dilakukan oleh peneliti dengan tujuan untuk menampilkan objek bahasan yang baru serta yang dekat dengan kehidupan nyata siswa. Dengan cara ini diharapkan pelajaran tidak membosankan, daya imajinasi siswa dikondisikan untuk semakin terlatih dan berkembang, gairah siswa untuk belajar tetap ada, dan yang paling penting adalah pengetahuan topik gambar makin dimiliki siswa. Dengan demikian diharapkan mereka lebih lancar dalam memproduksi pengetahuan mereka untuk disampaikan dalam secara lisan menjadi lebih lengkap dan lebih terorganisir. Semuanya itu diharapkan berpengaruh terhadap peningkatan hasil belajarnya.

Selanjutnya berdasarkan hasil refleksi disusun rencana tindakan siklus II, yang secara terperinci dalam skenario pembelajaran.

\section{d. Pelaksanaan Siklus II}

Tindakan Siklus II dilaksanakan dalam tiga kali pertemuan yaitu hari Kamis 7 April 2015, Kamis 14 April 2015, dan Kamis 21 April 2015pada siklus II ini semua tindakan guru sudah sesuai dengan rencana, hanya saja terjadi pergeseran waktu. Gambaran tindakan secara rinci sebagai berikut.

a) Deskripsi Kegiatan Pembelajaran

Siklus II

1) Pertemuan $I$ 
Dilaksanakan pada hari Kamis, 7 April 2015. Semua siswa Kelas VII hadir dan diabsen sesuai dengan nomor urut. Pada saat masuk ke kelas, guru mengucapkan salam. Setelah siswa menyatakan siap menerima pelajaran kemudian guru mengabsen siswa yang dilanjutkan dengan menyampaikan Kompetensi Dasar (KD) yaitu Mengobservasi dan menyajikan bentuk-bentuk dinamika interaksi manusia dengan lingkungan alam, sosial, budaya, dan ekonomi di lingkungan masyarakat sekitar (4.3) dan indikator dan dilanjutkan dengan melakukan, apersepsi, dan pengecekan kesiapan siswa untuk menerima pelajaran.

Kegiatan inti, Guru mendemonstrasikan kegiatan untuk mengoservasi dinamika yang terjadi di masyarakat terkait dengan interaksi manusia dengan lingkungannya (alam, sosial, budaya, ekonomi). Di samping itu, guru juga menunjukkan audio visualnya. Setelah dipandang siswa memahami materi yang disampaikan guru meminta siswa untuk berdiskusi sesama temannya yang sebangku, yang dilanjutkan dengan menyebutkan contoh kegiatan yang dapat dilakukan dalam mengobservasi interaksi yang dimaksud.

Mengakhiri pembelajaran guru bersama siswa melakukan suatu evaluasi mengenai beberapa pengertian dari pembahasan sebelumnya yang telah dibahas oleh siswa bersama guru, siswa juga diberikan beberapa tugas dalam menentukan suatu topik yang akan dibahas pada pertemuan berikutnya, dan diakhiri dengan pengucapan salam Paramasanthi.

2) Pertemuan II

Pertemuan II siklus II dilaksanakan pada hari Kamis, 14 April 2015, dan semua siswa Kelas VII hadir pada pertemuan ini. Pertemuan II diawali dengan mengucapkan salam yang dilanjutkan dengan presensi. Setelah mengabsen semua siswa hadir dilanjutkan dengan menyapaikan kegiatan pembelajaran yang melanjutkan pembelajaran sebelumnya. Selanjutnya guru bertanya tentang apa yang telah diperoleh siswa dari tugas rumah yang diberikan.

Guru menyampaikan apresiasinya terhadap yang telah dilakukan siswa dan guru memberikan penguatanmelalui tayangan gambar yang berkaitan dengan interaksi manusia dan lingkungan alam, sosial, budaya, ekonomi yang telah diobservasi oleh orangorang yang profesional dalam suatu penelitian.Setelah itu siswa diminta untuk berdiskusi sesuai dengan kelompoknya untuk lebih memahami. Setelah diskusi siswa diminta mendemonstrasikan kembali dengan menggabungkan apa yang telah dikerjakan dengan yang telah didemonstrasikan guru, baik melalui cara lisan maupun melalui audio visual.

Pengakhiran, guru bersama siswa melakukan penyimpulan dari hasil pembelajaran yang telah dilakukan. Guru menutup pelajaran hari itu dengan menyampaikan salam penutup

3) Pertemuan III

Pertemuan ketiga dilaksanakan pada hari Kamis minggu ketiga tanggal 21 April 2015 semua siswa Kelas VII hadir pada pertemuan ini, pada pertemuan ini tekanan yang 
dilakukan adalah pengulangan materi sebelumnya dan evaluasi. Mengawali proses pembelajaran guru mengucapkan salam dan dilanjutkan dengan menanyakan kesiapan siswa melaksanakan tes. Setelah itu guru melakukan persensi yang dilanjutkan dengan kegiatan inti.

Kegiatan inti, guru mengulang kembali materi yang sudah diajarkan pada pertemuan sebelumnya. Setelah selesai pengulangan yang dilakukan siswa diminta mengerjakan tes yang terkait dengan materi bersangkutan.

Pengakhiran, guru bersama siswa melakukan suatu evaluasi dan penyimpulan dan menutup pelajaran dengan mengucapkan salam penutup.

b) Hasil Tindakan Siklus II

Hasil Tes Akhir (kemampuan melaporkan peristiwa secara lisan) pada siklus II menunjukkan bahwa siswa/ yang dikategorikan bermasalah (belum tuntas) dalam melaporkan berbagai peristiwa secara lisan jumlahnya berkurang yaitu dari 14 orang pada siklus I (dengan peserta tes 35 orang) menjadi 5 orang pada siklus II (dengan peserta tes 35 orang). Dengan kata lain, siswa yang tuntas pada siklus II bejumlah 29 siswa, dan siswa yang belum tuntas 6 siswa.Berikut ini akan disajikan nilai hasil yang diperoleh siswa seperti terlihat dalam tabel berikut.

Tabel 04. Data Tes Hasil Belajar IPSSiswa PadaSiklus II

\begin{tabular}{|c|c|c|c|c|c|}
\hline No & $\begin{array}{l}\text { Nilai } \\
\text { Test }\end{array}$ & $\begin{array}{c}\text { Freku- } \\
\text { ensi }\end{array}$ & $\begin{array}{l}\text { Jumlah } \\
\text { Nilai }\end{array}$ & Nomor Absen Siswa & Ket \\
\hline (1) & (2) & (3) & (4) & (5) & (6) \\
\hline 1 & 65 & 6 & 390 & 1.2 .5 .7 .15 .26 & BT \\
\hline 2 & 70 & 17 & 1190 & $\begin{array}{l}\text { 4.6.9.11.12.13.14.17.18.19.23.27.29.30 } \\
.31 .33 .35 .\end{array}$ & $\mathrm{T}$ \\
\hline 3 & 75 & 5 & 375 & 3.8.10.22.25. & $T$ \\
\hline 4 & 80 & 7 & 560 & 16.20.21.24.28.32.34 & $\mathrm{T}$ \\
\hline \multicolumn{2}{|l|}{$\mathrm{N}$} & 35 & & & \\
\hline \multicolumn{3}{|l|}{$\sum X$} & 2515 & & \\
\hline \multicolumn{3}{|c|}{ Rata-rata Kelas } & 71,86 & & \\
\hline \multicolumn{3}{|c|}{ Daya Serap } & 71,86 & & \\
\hline \multicolumn{3}{|c|}{ Ketuntasan } & $82,86 \%$ & & \\
\hline
\end{tabular}

Jika dibandingkan dengan hasil tes akhir siklus I dapat dijelaskan bahwa pada siklus II ini 29 orang $(82,86 \%)$ nilainya sudah tuntas, hanya 6 orang $(17,14 \%)$ yang belum tuntas. Rata-rata nilai adalah 71,86 dengan yang terendah adalah 65 dan tertinggi adalah 80 . Hasil observasi juga memperlihatkan bahwa aktivitas siswa meningkat dari $25 \%$ menjadi $85 \%$. Indikator yang digunakan dalam melihat peningkatan aktivitas siswa adalah dari peran sertanya dalam diskusi, dan antusiasnya dalam bertanya dan menjawab di dalam kelas. Di samping itu juga dilihat dari tugastugas yang dikerjakan siswa.

Untuk mendapat gambaran lebih jelas tentang adanya peningkatan kemampuan, daya serap, dan ketuntasan siswa antara tes awal dengan tes akhir siklus I maupun II, maka ditampilkan ringkasannya pada tabel berikut ini. 
Tabel 05. Ringkasan Data Tes Awal dengan Tes Akhir Siklus I - II

\begin{tabular}{|c|c|c|c|c|c|c|c|c|}
\hline \multirow[b]{3}{*}{ No } & \multirow[b]{3}{*}{$\begin{array}{l}\text { Nilai } \\
\text { Tes }\end{array}$} & \multicolumn{2}{|c|}{ Test Awal } & \multicolumn{4}{|c|}{ Test Akhir } & \multirow[b]{3}{*}{ Keterangan } \\
\hline & & \multirow[b]{2}{*}{ Frekuensi } & \multirow[b]{2}{*}{$\begin{array}{l}\text { Jum- } \\
\text { lah } \\
\text { Nilai }\end{array}$} & \multicolumn{2}{|c|}{ Siklus I } & \multicolumn{2}{|c|}{ Siklus II } & \\
\hline & & & & Frekuensi & $\begin{array}{l}\text { Jum- } \\
\text { lah } \\
\text { Nilai }\end{array}$ & Frekuensi & $\begin{array}{l}\text { Jum- } \\
\text { lah } \\
\text { Nilai }\end{array}$ & \\
\hline (1) & (2) & (3) & (4) & (5) & (6) & (7) & (8) & (9) \\
\hline 1 & 50 & 8 & 400 & & & & & BT \\
\hline 2 & 55 & 2 & 110 & & & & & BT \\
\hline 3 & 60 & 14 & 840 & 16 & 960 & & & BT \\
\hline 4 & 65 & 3 & 195 & 9 & 585 & 6 & 390 & BT \\
\hline 5 & 70 & 8 & 560 & 3 & 210 & 17 & 1190 & BT \\
\hline 6 & 75 & - & - & 7 & 525 & 5 & 375 & BT \\
\hline 7 & 80 & - & - & - & - & 7 & 560 & $T$ \\
\hline \multicolumn{2}{|l|}{$\mathrm{N}$} & 35 & & 35 & & 35 & & \\
\hline \multicolumn{2}{|l|}{$\sum X$} & 2105 & & 2280 & & 2515 & & \\
\hline \multicolumn{2}{|c|}{$\begin{array}{l}\text { Rata-Rata } \\
\text { Kelas }\end{array}$} & 60,14 & & 65,14 & & 71,86 & & \\
\hline \multirow{2}{*}{\multicolumn{2}{|c|}{$\begin{array}{l}\text { Daya Seraf } \\
\text { Ketuntasan }\end{array}$}} & $60,14 \%$ & & $65,14 \%$ & & $71,86 \%$ & & \\
\hline & & 22,86 & & $28,57 \%$ & & $82,86 \%$ & & \\
\hline
\end{tabular}

Sumber: Tabel 06 dan 07

\section{c) Refleksi}

Berdasarkan hasil analisis data diadakan refleksi. Oleh karena hasil yang diperoleh dari pelaksanaan tindakan siklus II ini sudah menunjukkan peningkatan dibandingkan dengan siklus I baik dari segi proses maupun hasil tes akhir, serta siswa yang tuntas secara klasikal sudah 29 orang (sudah 82,60 \%), artinya sudah melebihi kriteria keberhasilan (70 $\%$ ), di samping itu semua permasalahan yang dikemukakan pada awal penelitian ini sudah terjawab, maka pada saat refleksi diputuskan penelitian ini diakhiri dan hasil penelitian ini menyatakan penerapan pendekatan konteks dalam Pembelajaran IPS dapat meningkatkan aktifitas hasil belajar pada siswa Kelas VII di SMP Negeri I Gianyar telah meningkat, dan hipostesis diterima.

\section{Pembahasan}

Pada pembahasan ini ditekankan pada sejumlah temuan yang dianggap menonjol dari keduasiklus yang telah dilakukan.
Berdasarkan uraian yang dikemukakan dalam penyajian hasil penelitian, sejumlah temuan yang dianggap menonjol adalah yang berikut ini.

1) Peragaan oleh guru, tanya jawab berkaitan dengan tayangan gambar-gambar tentanginteraksi sosial dan sosialisasi dan dipandu melalui pertanyaanpertanyaan/pernyataan dari guru, selain memicu tumbuhnya aktivitas siswa selama proses pembelajaran (baik aktivitas fisik maupun intelektual), juga membuat tingkat penguasaan siswa terhadap fokus pembelajaran yang menjadi materi menjadi semakin meningkat. Kondisi itu mengantarkan mereka menuju pada kemampuan yang lebih baik dalam mengaplikasikan materi yang diperoleh.

2) Memberikan kesempatan kepada siswa untuk berkomunikasi saat mendemontrasikan pokok materi yang dibelajarkan ketika unjuk kerja di depan kelas membuat siswa lebih baik dari segi 
keberanian penyampaian pendapat dan keruntutan dalam berpikir.

3) Diberikannya waktu yang memadai kepada siswa untuk berlatih sebelum melakukan unjuk kerja di depan kelas dengan pengawasan/bimbingan guru dapat meningkatkan hasil belajar siswa.

Temuan-temuan di atas dilatar belakangi oleh sejumlah aktivitas yang terjadi selama pembelajaran. Selama ini guru mengajarkan keterampilan masih dengan teknik konvensional tanpa diikuti dengan penggunaan media. Digunakannya metode demonstrasi dengan peragaan yang dibantu juga melalui media gambar dalam proses pembelajaran yang diikuti dengan teknik tanya jawab merupakan strategiyang cukup variatif dan inovatif yang ditempuh guru, sehingga siswa tertarik minatnya untuk belajar.

Strategi demontrasi yang ditempuh guru betul-betul efektif. Dengan strategi ini guru mengajak siswa untuk dapat mendemonstrasikan interaksi sosial dan sosialisasi yang dipelajari. Selain itu, pertanyaanpertanyaan/pemyataan yang dirancang oleh guru sedemikian rupa telah mampu menggiring siswa untuk menentukan memahami materi yang telah disampaikan.

Jadi, melalui strategi ini guru membelajarkan siswanya dengan beberapa peragaanyang diberikankepadadan siswa diberi kesempatan untuk mendemonstrasikannya apa yang diberikan guru. Hal tersebut menjadikan pembelajaran lebih bermakna bagi siswa. Dengan disertai dengan diskusi dan pertanyaan-pertanyaa kecil yang bersumber dan guru atau dan siswa telah membuat siswa aktif dan bergairah belajar. Ini berarti pembelajaran yang dikelola guru telah mencerminkan pembelajaran berbasis demonstrasi. Sebagaimana dikatakan bahwa banyak faktor yang menjadi penentu mutupembelajaran, salah satunya adalah bagaimana guru membelajarkan siswanya sehingga mau belajar. Dalam hal ini, untuk hal-hal sulit strategi belajar yang sesuai menjadi amat penting untuk ditempuh (Suastana, 2007:2).

Dengan demikian, hipotesis tindakan yang dirumuskan dalam PTK ini dapat dibuktikan, bahwa pembelajaran dengan menggunakan metode demonstrasi yang dilakukan di Kelas VIISMP Negeri I Gianyar ternyata mampu, meningkatkan aktivitas belajar siswa, dan mampu meningkatkan hasil belajar siswa.

\section{SIMPULAN}

Dari uraian diatas dapat dirumuskan beberapa simpulan dalam PTK yang dilakukan diKelas VII SMP Negeri I Gianyar, sebagai berikut:

1. Terdapat peningkatan aktivitas belajar siswa melalui penerapan metode pembelajaran demonstrasi dalam Pembelajaran IPS, yang dari semula hanya $25 \%$ menjadi $85 \%$.

2. Dari sisi hasil belajar siswa, terdapat peningkatan hasil belajar siswa yaitu dari yang semula nilai rata-ratanya hanya 60,14 meningkat menjadi 65,14 pada siklus I dan menjadi 71,86 pada siklus II. Sedangkan ketuntasan belajar siswa meingkat dari yang semula hanya dari $22,86 \%$ menjadi $28,57 \%$ pada siklus I dan menjadi $82,86 \%$ pada siklus II.

3. Di samping dua simpulan tersebut, melalui pembelajaran dengan metode demonstrasi siswa dapat memperoleh nilai tambah, yaitu terkait dengan adanya kepercayaan diri siswa dalam belajar dan keberanian untuk menyampaikan pendapat dalam diskusi dan tanya jawab. 
Mengacu pada hasil penelitian yang telah dikemukakan, terdapat beberapa saran yang dapat disampaikan diantaranya adalah:

1. Memperhatikan hasil yang dicapai dalam PTK ini, diharapkan kepada Kepala Sekolah SMP Negeri I Gianyar dapat memberikan rangsangan pada guru-guru yang mau pelaksanakan PTK sebagai langkah reflektif guru dalam meningkatkan kualitas pembelajaran, di samping peningkatan kualitas gurunya sendiri.

2. Kepada Guru-Guru di SMP Negeri I Gianyar, dalam kaitan untuk meningkatkan kreatifitas dan prestasi belajar siswa, diharapkan juga guru lebih kritis dalam membimbing siswa, baik akademis maupun non akademis, sehingga dapat menerapankan metode pembelajaran sesuai yang mampu membelajarkan siswa untuk belajar.

\section{PUSTAKA}

Ahmadi, Lif Khoiru dan Sofan Amri, $2011 . \quad M e n g e m b a n g k a n$ Pembelajaran IPS Terpadu. Analisis Kritis Tentang Metode, Strategi, Evaluasi dan Media Pembelajaran Bidang Studi Sejarah, Geografi, Ekonomi, Sosiologi, Antropologi, dan Isu Pembelajaran IPS Terpadu. Jakarta: Prestasi Pustaka Publisher.

Agung, A.A. Gede.1998. Pengantar Evaluasi Pendidikan. Singaraja: STKIP Singaraja

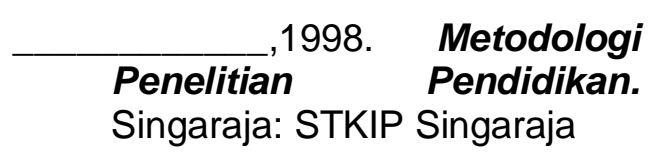

Dahar, Ratna Willis. 1998. Teoriteori Belajar. Jakarta: Pendidikan dan Kebudayaan
Depdikbud. 1994. Petunjuk Pelaksanaan Kegiatan Belajar Mengajar Kelas SMP. Jakarta: Depdikbud

Hadi, Sutrisno. 1986. Statistik I. Yogyakarta: Andi Offset

Hanafiah, Nanang \& Cucu Suhana. 2010. Konsep Strategi Pembelajaran. Bandung: RefikaAditama.

Hopkins, David. 1993. A Teacher's Guide Classroom Research. Philadelphia: Open University Press.

Gardner, Howard. 2003. Multiple Intellegencies Kecerdasan Majemuk Teori dalam Praktik. Terjemahan Alexander Sindoro. Judul Asli: Multiple Intelligences. Jakarta: Interaksara

Mulyasa, H.E. 2008. Implementasi Kurikulum Tingkat Satuan Pendidikan. Kemandirian Guru dan Kepala Sekolah. Jakarta: Penerbit Bumi Aksara.

Nurkencana, Wayan dan P. P.N. Sunartana.1986. Evaluasi Penndidikan. Surabaya: Usaha Nasional.

Rusyan,A. Tabrani.1993. Proses Belajar Mengajar Yang Efektif Tingkat Pendidikan Dasar. Bandung: Bina Budhaya.

Sardiman.A.M. 2011. Interaksi dan Motivasi Belajar Mengajar. Jakarta: Rajawali.

Tilaar, H.A.R. 2001. Agenda Reformasi Pendidikan Nasional Menyongsong Indonesia Baru. Jakarta: PT. Grasindo. 